\title{
SMALL GLACIERS IN THE DINARIC MOUNTAINS AFTER EIGHT YEARS OF OBSERVATION: ON THE VERGE OF EXTINCTION?
}

Emil Mariov Gachev

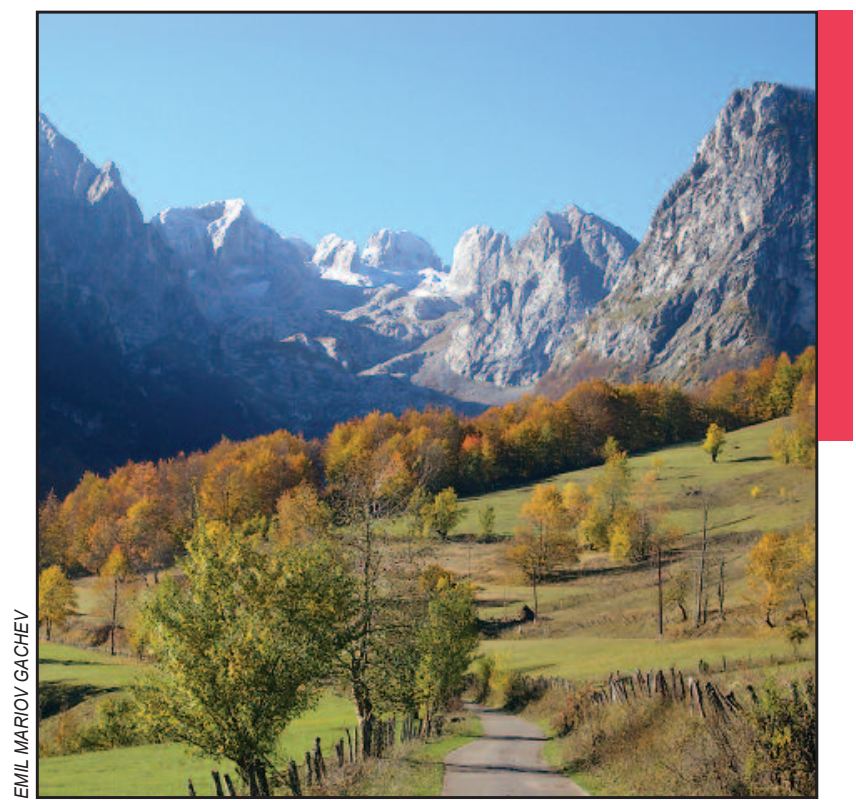

The Prokletije Massif: the great Grebaje Cirque. The lowermost perennial ice masses in southeast Europe still survive among these magnificent limestone cliffs. 
DOI: https://doi.org/10.3986/AGS.8092

UDC: $551.324: 551.58(234.422 .1) \ll 2011 / 2018 \ll$

COBISS: 1.01

Emil Mariov Gachev ${ }^{1,2}$

\section{Small glaciers in the Dinaric Mountains after eight years of observation: On the verge of extinction?}

ABSTRACT: This study presents results from regular observation of permanent and summer-persisting firn-ice bodies in the highest parts of the Dinaric Alps. The sizes of six small glaciers and two snow patches on the Prokletije Massif (in Albania) and the Durmitor Massif (in Montenegro) were measured from 2011 to 2018. In recent years, specific cycles of interannual behavior have been observed: a year of considerable snow accumulation ( $\mathrm{a}$ »recharge « phase), followed by two to four years of gradual decrease (a »wastage" phase). At present, the small glaciers studied exist in unbalanced conditions, which in the long term may lead to their degradation. Progressive warming makes short-term cycle minimums increasingly severe. Their retreat after the summer of 2017 was probably the most pronounced since the Little Ice Age, and small glaciers are on the verge of extinction.

KEYWORDS: glacierets, snow patches, warming, winter precipitation, interannual variations, Dinaric Mountains

\section{Majhni ledeniki v Dinarskem gorovju po osmih letih opazovanja: na robu izumrtja?}

POVZETEK: Članek predstavlja rezultate rednih opazovanj trajnih malih ledenikov, ledeniških krp in snežnih zaplat v najvišjih delih Dinarskega gorstva. V obdobju 2011-2018 smo merili velikost šestih ledenikov in dveh snežnih zaplat v Prokletijah (Albanija) in na Durmitorju (Črna gora). V zadnjih letih opažamo posebne cikle medletnega kolebanja: leto velike akumulacije snega (faza "vnovičnega polnjenja «), ki mu je sledilo dve do štiri leta postopnega krčenja (faza "praznjenja«). Preučeni majhni ledeniki so trenutno v neuravnoteženih razmerah, kar lahko dolgoročno povzroči njihovo izginotje. Progresivno segrevanje še poglablja kratkoročne ciklične minimume. Njihovo zmanjšanje po poletju 2017 je bilo verjetno najmočnejše po mali ledeni dobi, majhni ledeniki pa so na robu izginotja.

KLJUČNE BESEDE: majhni ledeniki, snežne zaplate, segrevanje, zimske padavine, medletne razlike, Dinarsko gorstvo

The paper was submitted for publication on March $10^{\text {th }}, 2020$.

Uredništvo je prejelo prispevek 10. marca 2020.

\footnotetext{
${ }^{1}$ South-west University »Neofit Rilski«, Blagoevgrad, Bulgaria

${ }^{2}$ National Institute of Geophysics, Geodesy, and Geography, Sofia, Bulgaria emil.gachev@swu.bg (https://orcid.org/0000-0002-8832-0273)
} 


\section{Introduction}

Glaciers are among the best indicators of climate change. Local and regional glacier studies (Pavšek 2007; Pecci, D’Agata and Smiraglia 2008; Hohenwarter 2013; Gabrovec et al. 2014; Colucci et al. 2014; Colucci 2016; Colucci and Žebre 2016) are important because their results further improve global climate change models and make possible more accurate forecasts for environmental changes in particular locations.

The highest massifs of southeastern Europe still provide conditions marginal for glacier formation (Hughes 2009; Grunewald and Scheithauer 2010; Figure 1). Because they are located 500 to $700 \mathrm{~m}$ below the theoretical elevation of the present-day glacier equilibrium-line altitude (ELA), their existence is determined by local topography.

Two main categories of firn-ice bodies can be distinguished in the area: 1) small glaciers (mostly categorized as glacierets), and 2) ice/snow patches. Small glaciers are permanent tiny masses of snow, firn, and ice (measuring 0.5 to 5 hectares) that show dynamic motion of their mass under the force of gravity (Grunewald and Scheithauer 2008; 2011). Due to their modest mass, ice patches do not show signs of motion, except some minor displacements (Serrano et al. 2011); however, they can in fact be permanent. Snow patches, on the other hand, may last for up to several consecutive summers, but they melt completely at least once every few years. Small firn-ice bodies often switch between these categories due to significant shortterm variations.

In the Dinaric Mountains, annual and multi-annual preservation of firn and ice occurs in a few specific locations with special topoclimatic conditions: shading (in deep glacio-karst depressions with a northern or northeastern exposure) and carbonate bedrock, which warms less due to its light color (Popov 1964; Lipar et al. 2020) and is permeable due to karst processes that hinder basal melt. Abundant winter snow is provided by considerable precipitation, along with contribution from avalanches and windblown snow, which can effectively increase snow accumulation over the glacier surface up to several times (Hughes 2007; 2008). Temperatures should be low enough in order to achieve relatively low ablation rates. Glaciers in the Dinaric Mountains appear at elevations above $1,900 \mathrm{~m}$, but at lower elevations compared to most of the Alps and the mountains of Southeast Europe.

Glacial-type motion has been evidenced for a number of firn-ice bodies on the highest massifs of the Dinaric range, Prokletije and Durmitor, mainly on the basis of their morphology and the presence of fresh glacial striations on bedrock in their vicinity (Gachev 2017). This article summarizes studies of the interannual changes in selected small glaciers and snow patches in the Dinaric Mountains (Figure 1) in recent years and presents the main reasons for the trends observed as a consequence of regional climate change.

\section{Study sites}

The Dinaric Mountains extend along the Adriatic shores of the Balkan Peninsula, from Slovenia in the northwest to Albania in the southeast. Prokletije $(2,694 \mathrm{~m})$ and Durmitor $(2,522 \mathrm{~m})$ are the highest and second-highest massifs in this range.

\subsection{The Prokletije Massif}

The mountainous Prokletije Massif, measuring $70 \times 40 \mathrm{~km}$, is mainly located in northern Albania, on the borders with Montenegro and Kosovo. Many of its ridges rise to 2,000 to 2,400 $\mathrm{m}$. The highest summit is Mount Jezerca (Alb. Maja e Jezercës, SCr. Maja Jezerce, 2,694 m).

The geology of the Prokletije Massif is diverse. Limestone dominates in the center, south, and west, whereas the eastern part is mostly built of silicate rock (Dimitrijević 1983). During the Pleistocene, the glacier extent on the Prokletije Massif was considerable. In the cold phases prior to the Last Glacial Maximum (LGM), the ELA dropped to $1,750 \mathrm{~m}$, and glaciers over $10 \mathrm{~km}$ long flowed down from the central highest parts (Milivojević, Menković and Ćalić 2008).

The presence of contemporary glaciation in the limestone part of the Prokletije Massif north of Mount Jezerca, "an ice mass about $1 \mathrm{~km}$ long, " was first mentioned by Ludwig Roth von Telegd (1923). Milivojević, Menković, and Calić (2008) mapped three small glaciers in the same part of the mountain, with a total area of about 11 hectares, with the largest (the Koljaet Glacier) occupying about 5 hectares. Hughes (2009) 


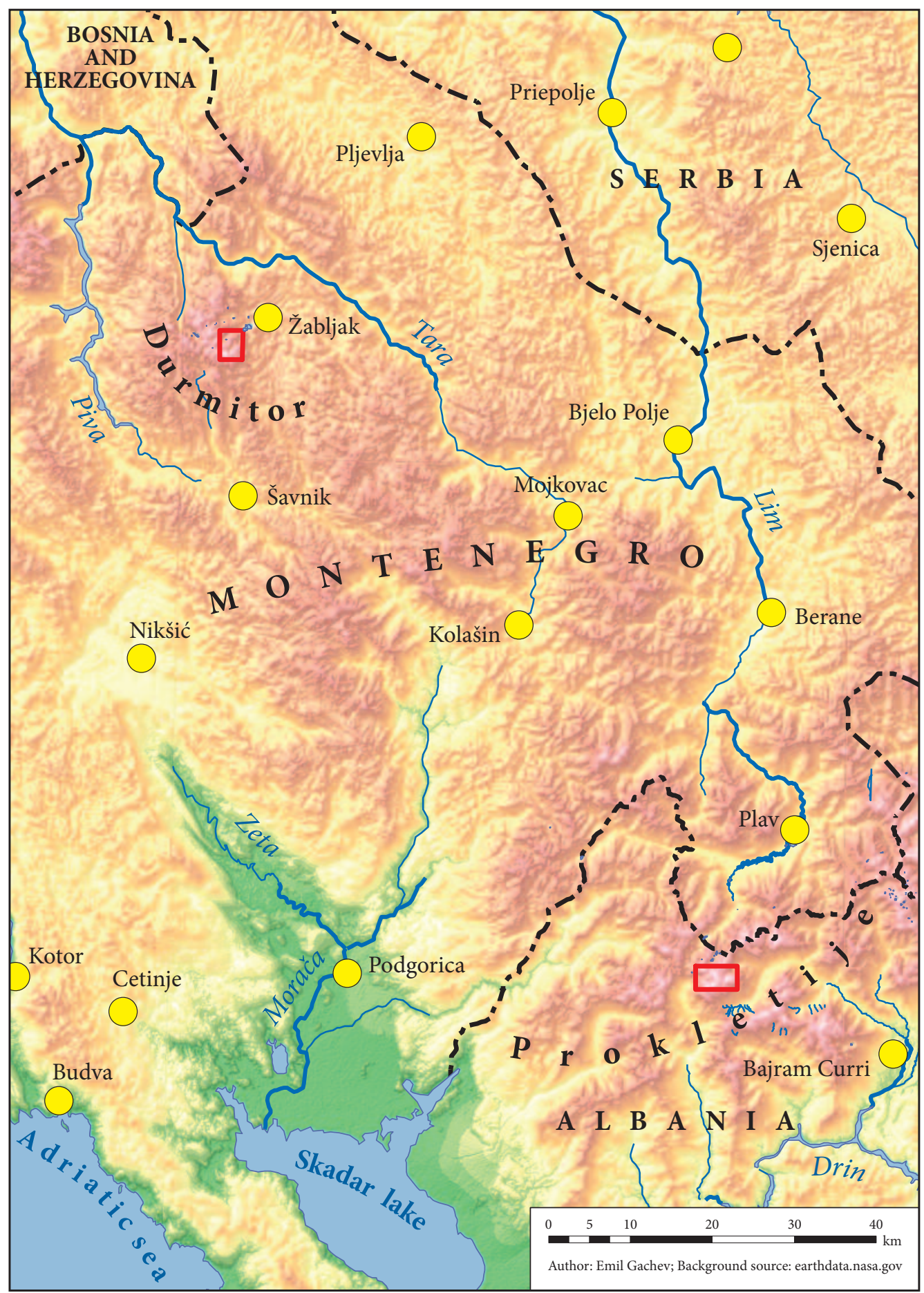

Figure 1: Location of the study sites in the Prokletije Massif and the Durmitor Massif, where monitored small glaciers are situated. Red rectangles show the sites of the present study areas. 
mentioned one more glacier with an area of 4.9 hectares, and two more glaciers were described by Gachev and Stoyanov (2012). In 2012 a glacieret (2.2 hectares) was discovered in the Kolata range $(2,556 \mathrm{~m})$. In 2015, five small glaciers were mapped in the range south of the Valbona Valley and two in the Karanfili range $(2,490 \mathrm{~m})$, among them the lowest in the Balkans, at 1,910 to 1,970 $\mathrm{m}$ (Gachev, Stoyanov and Gikov 2016). According to the author's observations, the Koljaet Glacier should instead be referred to as a snow patch because it melted completely in 2012 and 2016. Objects of the previous study are the five glacierets and two snow patches in the central part of the Prokletije Massif (Figure 2). The glacierets lie at elevations from 2,300 to 2,480 $\mathrm{m}$ on a rocky terrace below the summit of Mount Jezerca $(2,694 \mathrm{~m})$ and have a northern to northeastern orientation. The Jezerce I and II Glacierets are located at the base of a rock wall (Figure 2, bottom left), whereas the Jezerce III Glacieret, further to the southeast, is a compound-type glacieret (Figure 2, bottom right). Its upper (northwest) section lies against a rocky wall base, and the lower section comprises a series of dolines. A set of moraines outlines the lower margins of those glacierets. For several years, Jezerce III was recorded as the largest glacieret in the Balkans. The Jezerce IV and V Glacierets occupy rocky depressions and have weakly developed moraines.

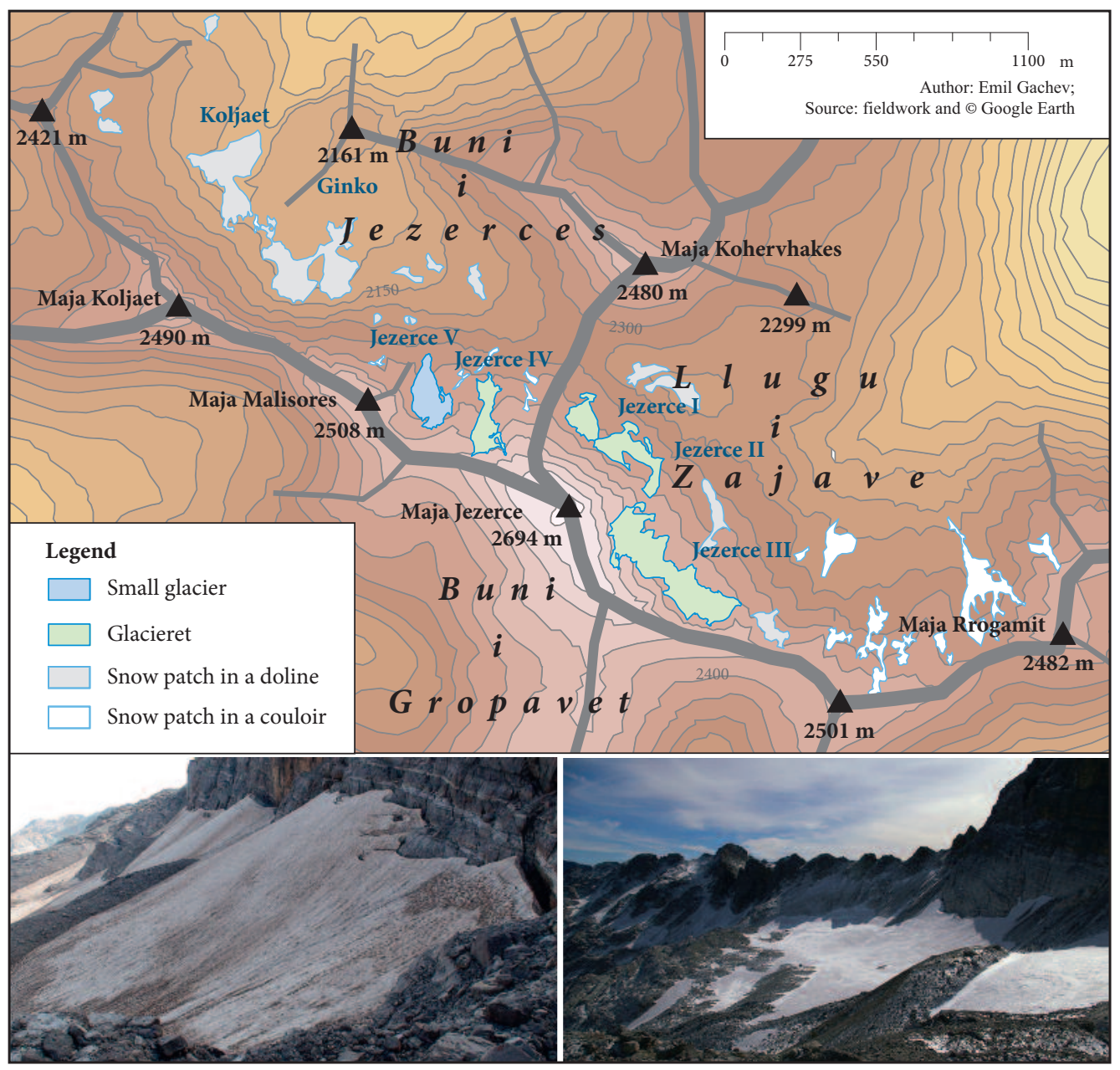

Figure 2: Small glaciers and snow patches in the Mount Jezerca area (Prokletije Massif, Albania). Top: Small glaciers and snow patches in the Mount Jezerca area, Prokletije Massif, Albania (height difference between contour lines is $50 \mathrm{~m}$ ). Bottom left: the glacierets Jezerce I (in the front) and II (in the back). Bottom right: Jezerce III glacieret. Photos were taken by Emil Mariov Gachev. 
Two long-lasting snow patches cover the floor of the Buni i Jezercës Cirque at 1,980 to 2,100 m: the $L$-shaped Koljaet Snow Patch and the double Ginko Snow Patch. In some years the snow thickness in late summer can reach $10 \mathrm{~m}$, and the patch may entirely disappear in others.

\subsection{The Durmitor Massif}

The Durmitor Massif (with its highest peak Bobotov Kuk, 2,522 m) is a relatively small mountainous area in northwest Montenegro (123 km²; Cerović 1991; Figure 3). It rises above a hilly karst plain with an elevation of 1,450 to $1,600 \mathrm{~m}$ that borders it to the east, northeast, and northwest.

The Dumitor Massif is built of carbonate rock (Mirković 1983). Thick limestones and dolostones compose its northern and central parts, including the main ridge and the highest peaks. To the southwest they make contact with flysch via a linear nappe structure (Djurović 2011).

The Durmitor Massif was heavily glaciated in the Pleistocene. The ELA of the maximum Pleistocene glaciation was at about 1,400 to 1,600 m (Djurović 2009; Hughes et al. 2011), and glaciers reached far beyond the mountain margins (Hughes and Woodward 2008). Several vast and deep cirques were carved on the northern slopes.

Today only one tiny glacier exists on the Durmitor Massif: the Debeli Namet Glacier in the deep Velika Kalica Cirque (Figure 3). The glacier lies at an elevation of 2,035 to 2,200 $\mathrm{m}$ and is oriented to the north-northeast. Its length is usually about 300 to $320 \mathrm{~m}$ and its width 120 to $140 \mathrm{~m}$. A concave upper section and a convex lower part, surrounded by a high moraine, are distinguished. The glacier lies at the base of a rock wall 200

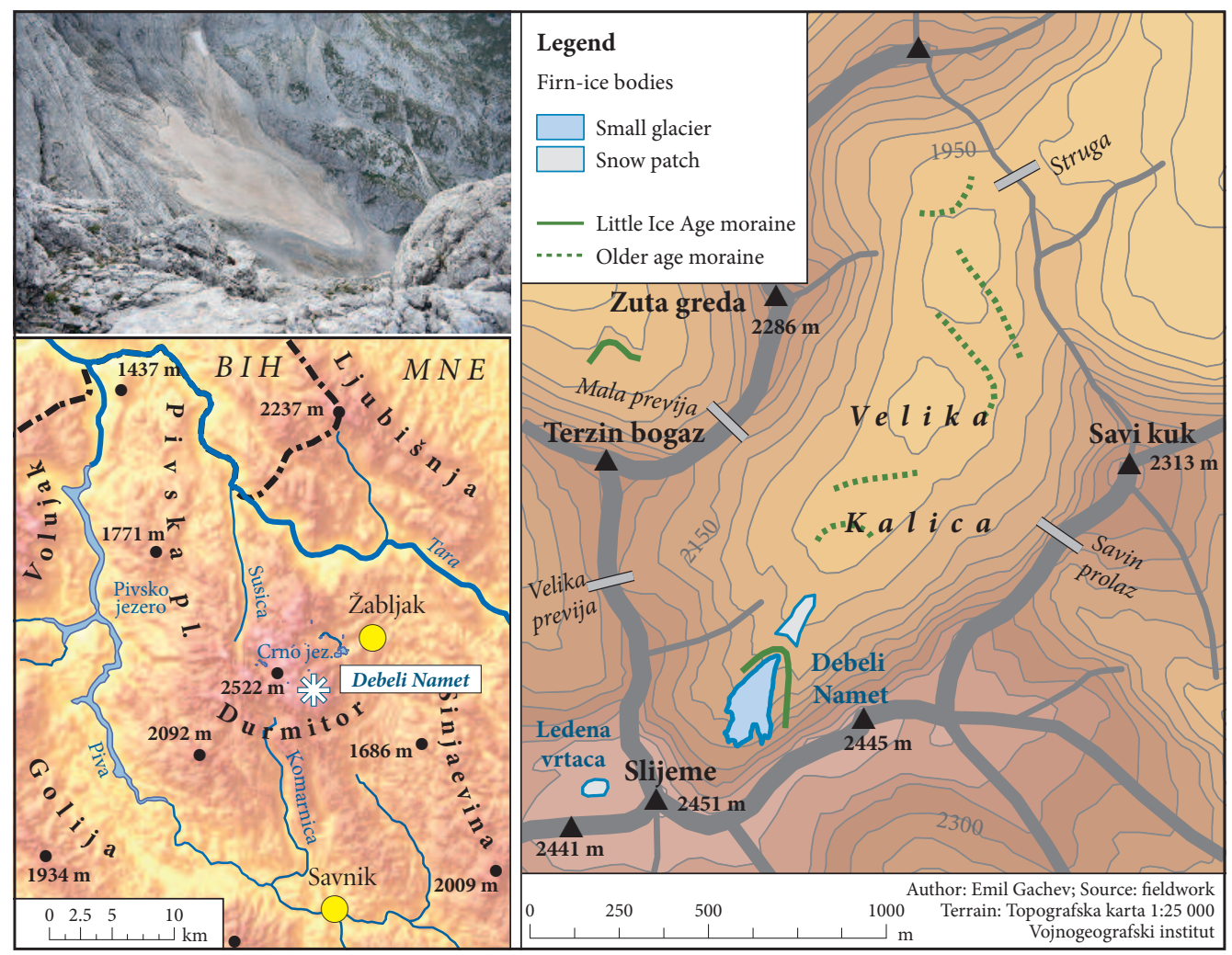

Figure 3: Location of the Durmitor Massif and the Debeli Namet Glacier. Botton left: location of the Durmitor Massif and the Debeli Namet Glacier (digital elevation model by US Geological Survey). Right: a map of Velika Kalica cirque with firn-ice bodies (height difference between contour lines is $50 \mathrm{~m}$ ). Top left: the Debeli Namet glacier in October 2018. Photo was taken by Emil Mariov Gachev. 
to $250 \mathrm{~m}$ high. On top of it a small plateau serves as an additional snow source area during winter. The glacier was researched by Nicod (1968), Djurović (1999), and Kern et al. (2007). Hughes (2007) studied the surrounding moraines using lichenometry and dated it to 1878-1904. Later, Hughes (2008) presented size measurements of the glacier for the period from 2003 to 2007 and analyzed the climate factors for glacier existence. The most detailed information on the glacier's morphology and size was provided by Djurović (2012).

\section{Methods}

The research for this study was carried out from 2011 to 2018 and consisted of three stages: examining satellite images and maps, fieldwork at the end of the annual glacier mass balance cycle (usually in October), and data analysis and summarizing the results.

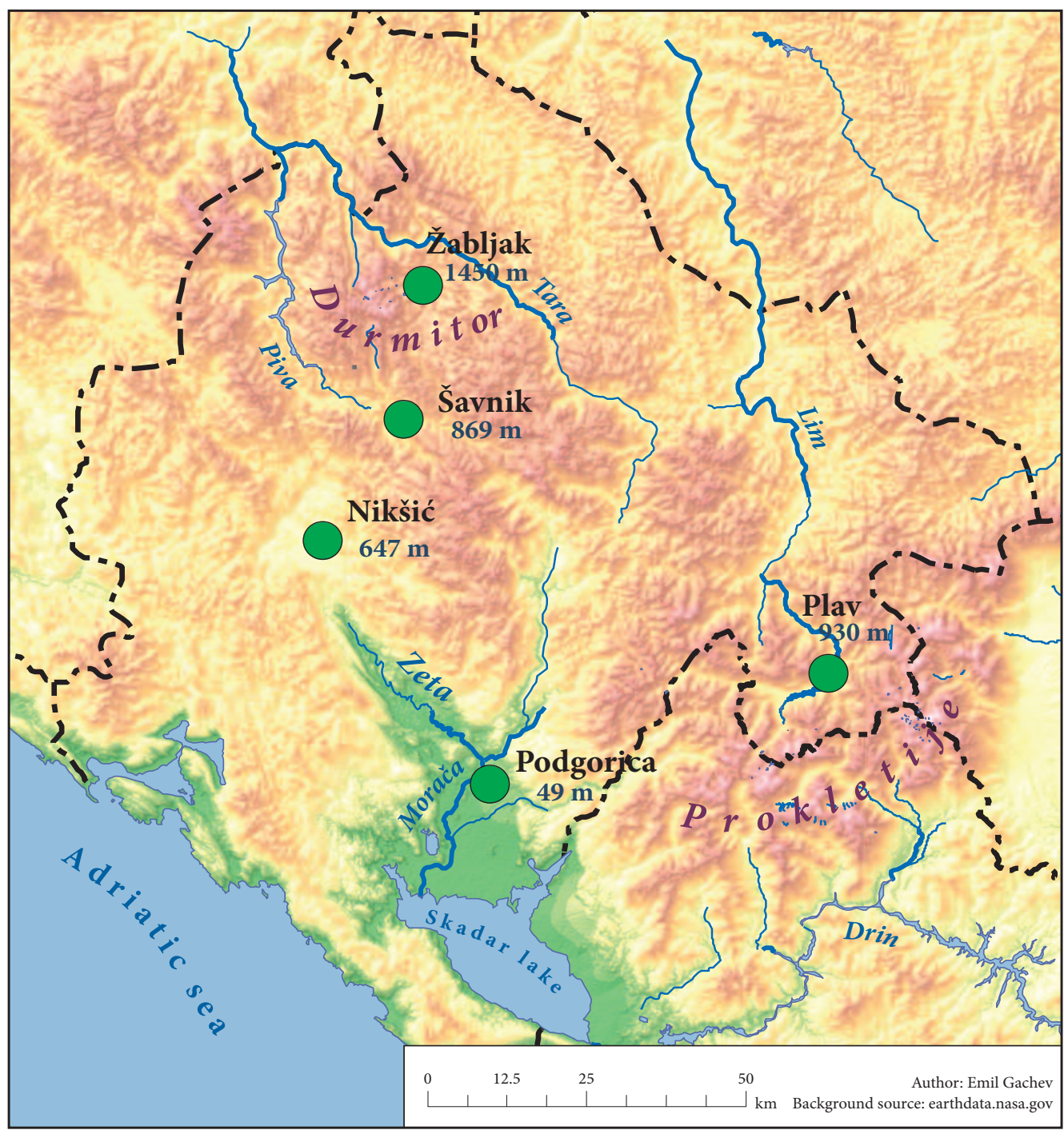

Figure 4: Meteorological stations in Montenegro (with elevations) referred to in this paper (image background: ASTER DEM by earthdata.nasa.gov). 
Good-quality Google Earth images are available for the Prokletije Massif for October $29^{\text {th }}, 2006$, October 4th, 2013, September 30th, 2016, and August 31st, 2018. They were used to set the targets for fieldwork.

The areas of the observed glacierets and snow patches in the Prokletije Massif were calculated based on field measurements, GPS recordings, and photographs from fieldwork. A laser range finder was used to measure the lengths, widths, heights, and slope tilts of landforms. Changes in firn/ice levels were recorded in the field using paint marks. For the Debeli Namet Glacier, rope measurement of its greatest length and width was performed in 2011, and then the area was calculated by digitizing a photograph taken in the field from a remote position. Between 2012 and 2018, areas were processed by overlaying photographs taken from the same position. The area for 2019 was calculated based on a photograph from September 30th, available on the website of the Institute of Hydrometeorology and Seismology of Montenegro (Zavod za hidrometeorologiju i seizmologiju Crne gore; Internet 1). The size for September 1998 was calculated from our photograph.

For the analysis of climate, temperature data are available for Podgorica from 1949 to 2009 (Internet 1,2). Monthly temperatures and precipitation for five stations (Figure 4) were retrieved from the annual bulletins of the Montenegrin institute (Godišnjak ... 2010; 2011;2012; 2013; 2014; 2015; 2016; 2017; 2018), as well as data on monthly snow cover thickness for Plav, Žabljak, and Šavnik. Since the autumn of 2017, the ground temperature at the moraine near the Debeli Namet Glacier has been monitored on an hourly basis by a temperature logger with an accuracy of $0.3^{\circ} \mathrm{C}$.

Simple positive degree-day models were calculated for the sites of the Debeli Namet Glacier and for an altitude of 2,400 $\mathrm{m}$ in the area of Mount Jezerca from 2011 to 2018, on the basis of extrapolated temperature data from the stations at Žabljak and Plav, respectively, using a lapse rate of $0.55^{\circ} \mathrm{C} / 100 \mathrm{~m}$.

For the analysis, climate data were summarized in accordance with the glacier mass balance year, which lasts from November to October (Gachev, Stoyanov and Gikov 2016). The accumulation season is presented by the data from December to March, and the ablation season by the data from June to September.

\section{Results}

\subsection{Size of firn-ice bodies}

Changes in the total area of the glaciers and snow patches monitored on the Prokletije Massif in the autumn (Table 1, Figure 5) show a gradual decrease in size, followed by a sharp increase.

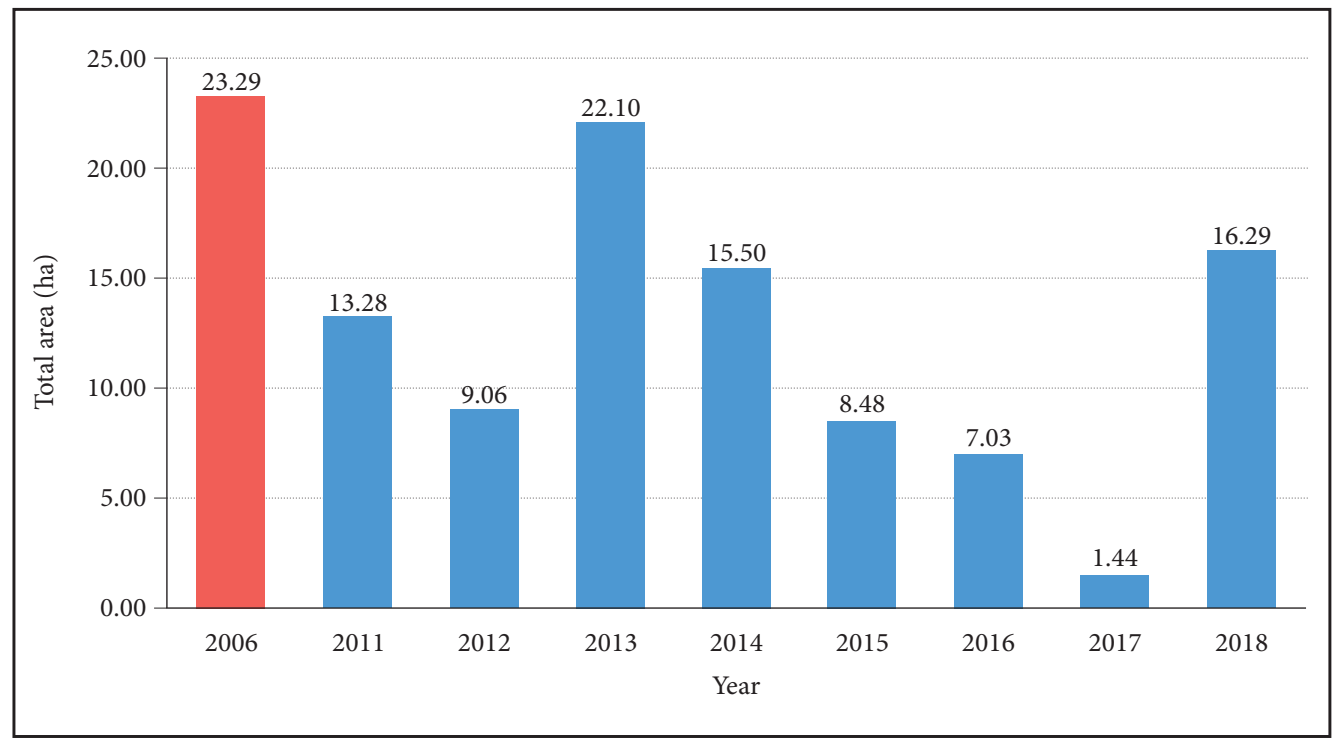

Figure 5: Total area of monitored glacierets and snow patches near Mount Jezerca (Prokletije Massif) for 2006 and 2011-2018. 


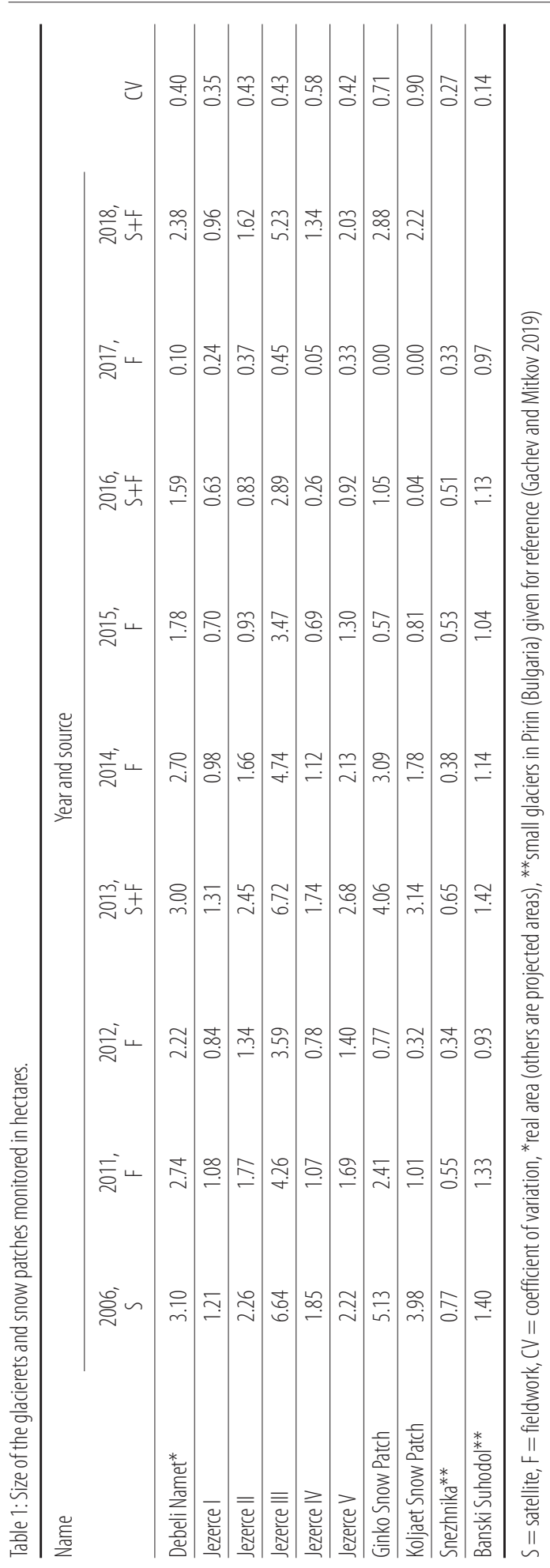




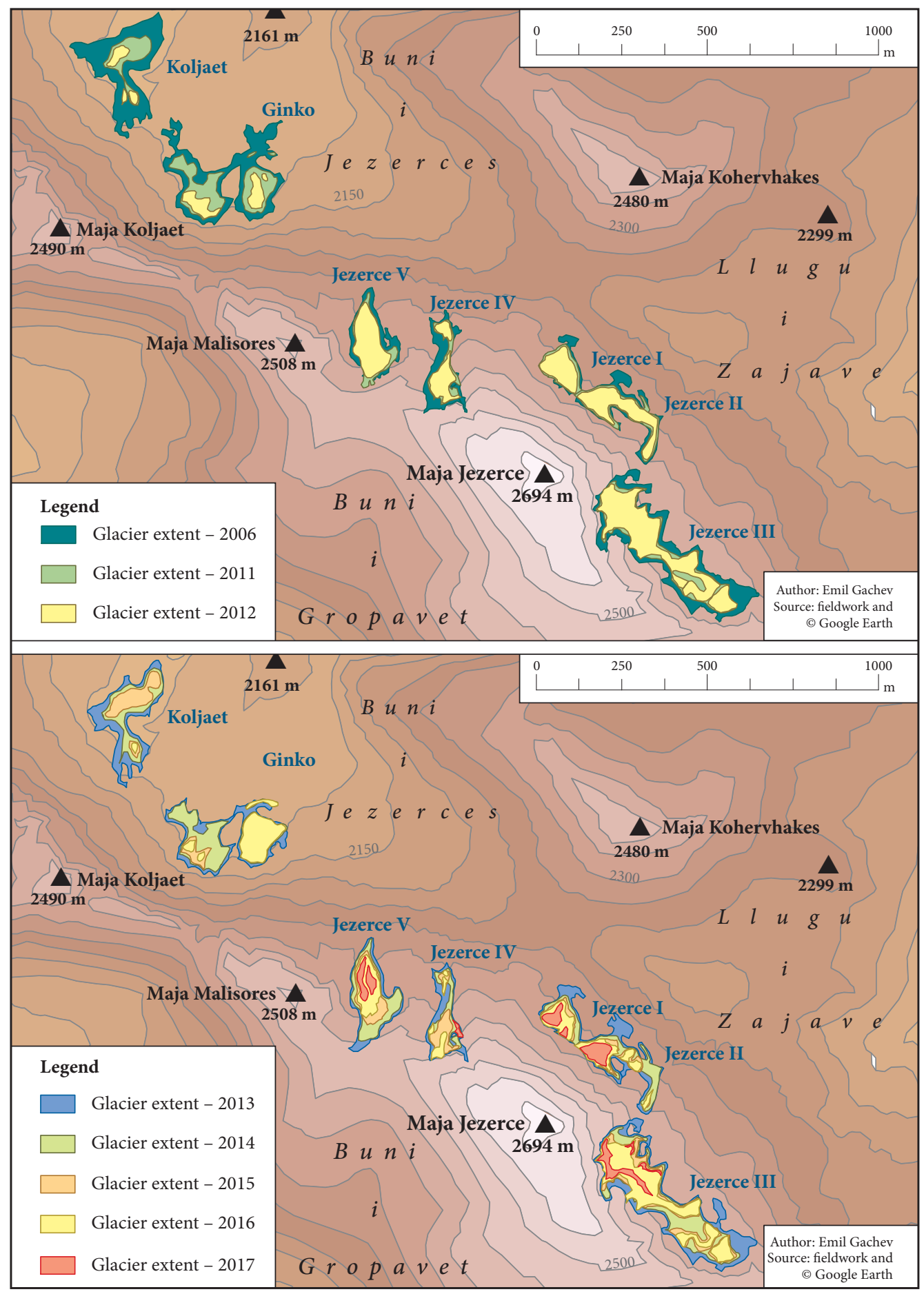

Figure 6: Spatial extent of small glaciers and snow patches in the area around Mount Jezerca (Prokletije Massif) for 2006, 2011, and 2012 (above) and 2013-2017 (below). Height difference between contour lines is $50 \mathrm{~m}$. 


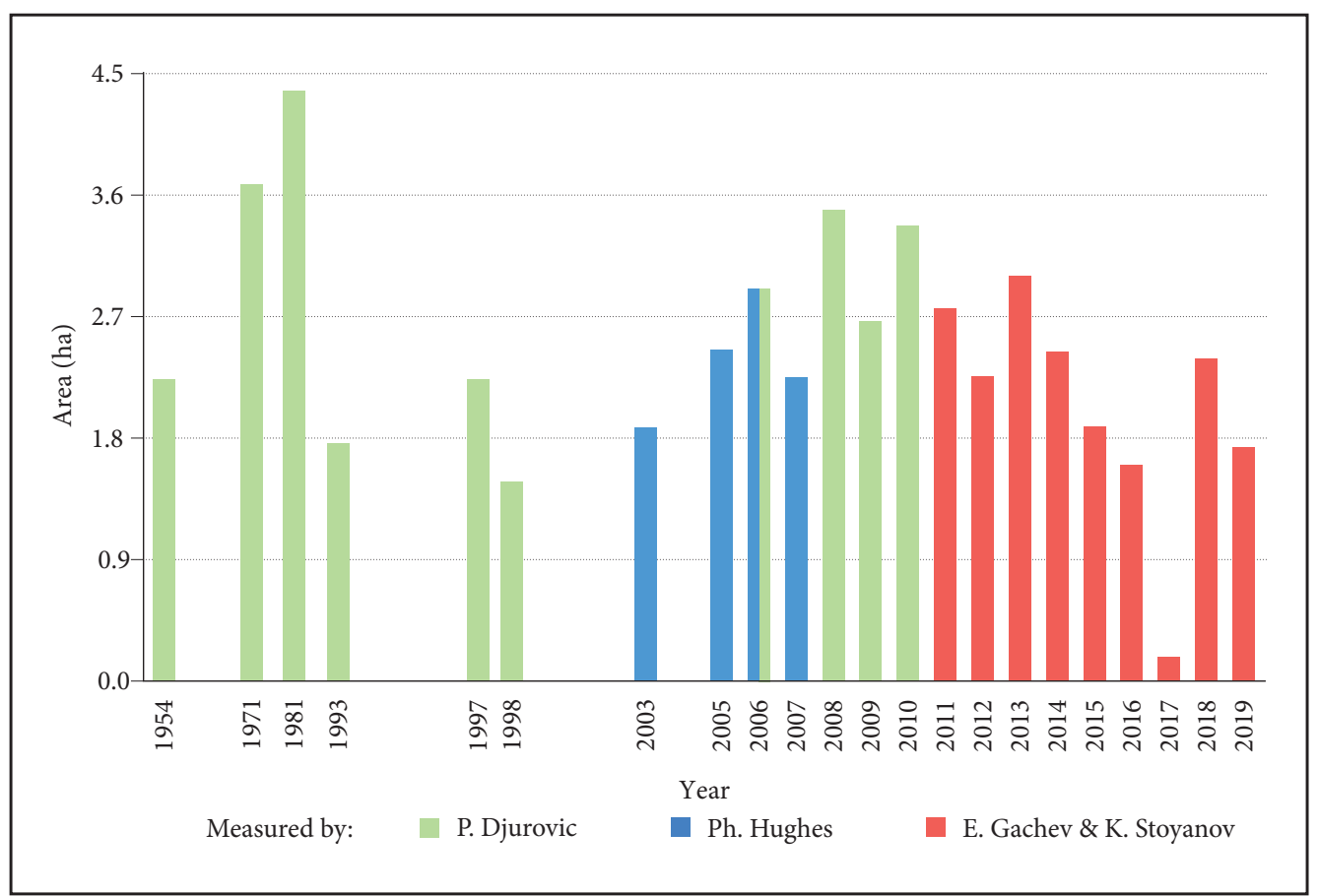

Figure 7: Area of the Debeli Namet Glacier from 1954 to 2019 in hectares.

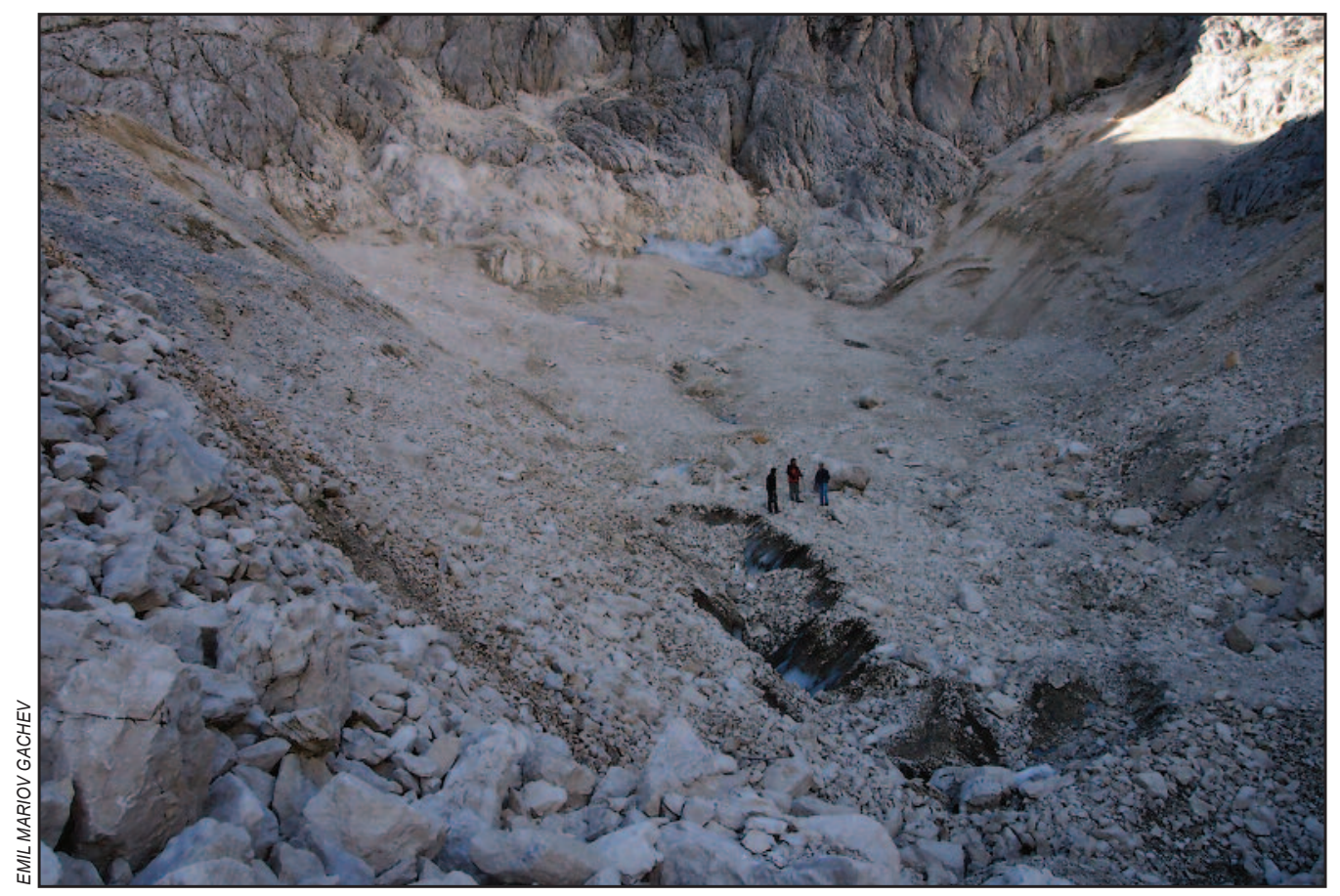

Figure 8: The Debeli Namet Glacier in October 2017. 
Snow patches have a much higher amplitude of size variation than glacierets, which is demonstrated by the values of the coefficient of variation (CV) in Table 1 . The severe reduction of glaciers and their transition into ice patches is often accompanied by fragmentation into parts (Del Gobbo et al. 2016), fragmentation itself depending on the topography of each site. In the area of Mount Jezerca, fragmentation reached its maximum in 2016, when the six firn-ice bodies were scattered into seventeen fragments (Figure 6).

The Debeli Namet Glacier on the Durmitor Massif has been studied much more in terms of size (Figure 7). Here again, several series can be outlined, which start with a sharp increase in area and continue with a gradual decrease in the following few years. Due to its simpler glacier topography, no fragmentation has been observed, only perforation of the middle section in some years.

The results from Table 2 and Figures 5 and 6 demonstrate negative trends in the development of all firn-ice bodies for the period observed. In the autumn of 2017, the snow patches completely melted and all the glacierets turned into minor ice patches. Debris fields partly cemented with ice were largely exposed on the surface. Corroded by the melt streams, the residual ice at the Jezerce III Glacieret still had a visible thickness of at least several meters. Exposed ice-cemented debris was also recorded at the bottom of the melted Koljaet Snow Patch. Only a tiny white spot measuring 0.1 hectare was left from the Debeli Namet Glacier. Again, some ice layers several meters thick were recorded under the debris in the lower section of the glacier depression (Figure 8).

Another recovery of glaciers was witnessed in 2018, when in September up to $5 \mathrm{~m}$ of the previous winter's snow was measured in the cirques on the Prokletije and Durmitor Massifs. The latest observations from the autumn of 2019 show that the Debeli Namet Glacier shrank by about $30 \%$ compared to the previous year, and the record low snow for the winter or 2019/2020 (Internet 1) is a prerequisite for a further reduction.

\subsection{Characteristics of climate}

Warming since the second half of the nineteenth century has led to severe glacier retreat worldwide. However, climate change at the regional and local scale can differ from what is observed globally. This also applies to the reaction of small glaciers, which greatly depends on topography (Zemp et al. 2008).

In the area studied on the Prokletije Massif, traces of fresh moraines below the Koljaet Snow Patch (Wilkinson 2011) and the Jezerce III Glacieret indicate that during the Little Ice Age (LIA) the glaciation was much larger. Evidence for large LIA glaciers in several other cirques on the Durmitor Massif were confirmed by Hughes $(2007,2010)$.

In the last sixty years, the mean annual air temperature at Podgorica (Figure 9) rose by $1.2^{\circ} \mathrm{C}$, but the warming has been much more pronounced during the last four decades $\left(0.45^{\circ} \mathrm{C}\right.$ per decade). Comparing the period from 2010 to 2018 with the standard (1961-1990), the greatest rise has been for summer temperatures $\left(2.4-3.0^{\circ} \mathrm{C}\right)$, and the lowest for winter temperatures $\left(0.3-1.6^{\circ} \mathrm{C}\right)$.

From 1951 to 2010 , no trend was observed in annual precipitation, but the following general episodes can be outlined: dry (1951-1957), wet (1958-1985), dry (1985-2003), and wet (2004-2010; Ducić et al. 2011). The period from 2005 to 2014 was rather wet, and from 2015 to 2018 the precipitation amounts were around the average for the period 1951 to 2010 (Internet 2). A very weak negative trend was observed from 1951 to 1990 for winter precipitation (Ducić et al. 2011), but a considerable rise was recorded after the dry period at the beginning of the 1990s.

The climate fluctuation between dry/wet and warm/cool conditions determined smaller glacier sizes in the 1950s, larger in the 1960s and 1970s, and a strong recession in the 1980s and 1990s (Figure 7).

In the last decade, average temperatures were 1.3 to $1.8^{\circ} \mathrm{C}$ higher than those for the standard period, and the climate showed notable variations (Godišnjak ... 2010; 2011; 2012; 2013; 2014; 2015; 2016; 2017; 2018; Burić, Micev and Mitrović 2012).

Summer temperatures determine the overall rate of ablation. The hottest was the summer of 2012, followed by 2015 and 2017 (Figure 10). In a long-term context, at Žabljak the »normal « summer temperatures (June-September) for 2010 to 2018 are $2.1^{\circ} \mathrm{C}$ higher than for 1961 to 1990 . On the other hand, the average winter precipitation (December-March) was 37\% higher than that of the standard period, whereas summer rains decreased by $16 \%$. Therefore, small glaciers and snow patches continued to exist in the second decade of the twenty-first century, despite the pronounced warming (with smaller sizes than during the 1970s and 1980s). 
Precipitation from 2010 to 2018 was quite variable. For the period from December to March, maximum amounts were recorded in 2013 and 2018, and for June to September in 2014 (in western Montenegro) and in 2016 (to the east).

Based on snow cover data for Žabljak, Šavnik, and Plav, the winter of 2011/2012 can be defined as »very snowy, « 2012/2013 and 2014/2015 as »snowy, « 2010/2011 and 2017/2018 as »moderate, «2015/2016 and 2016/2017 as winters with »little snow, « and 2013/2014 as a »snowless « winter. At Plav, at $930 \mathrm{~m}$, the record snow thickness, registered in February $2012(176 \mathrm{~cm})$, approached that at Žabljak $(208 \mathrm{~cm})$, situated at 1,450 m. The local conditions around glaciers, however, are quite different from those on a free slope. In 2017/2018 the temperature logger at the Debeli Namet Glacier at 2,035 m registered 247 days with snow, compared to only 149 days at Żabljak (Internet 1).

\subsection{Glacier fluctuation and climate}

The correlation between precipitation for the glacier accumulation season (November-April) at Žabljak and the size of the Debeli Namet Glacier for the 2009/2010 to 2017/2018 balance years is strong, reaching +0.70 . When compared to precipitation at Nikšić, which is in a windward position to the moist air masses from the southwest, the correlation is +0.86 . Similar is demonstrated by the relationship between the sizes of glacierets on the Prokletije Massif and precipitation at Plav for the same period: the correlation is between +0.74 and +0.81 . On the other hand, simple degree-day models for the Žabljak and Plav stations do not show any appreciable relationship between glacier size variations and ablation temperatures. Although the observation period is quite short, these results indicate the leading role of winter precipitation for shortterm glacier fluctuations.

A detailed analysis of the relations between glacier size and climate year by year is presented below. For reference, interannual size changes of firn-ice bodies and the main climate factors, presented in relative units, are shown in Table 2.

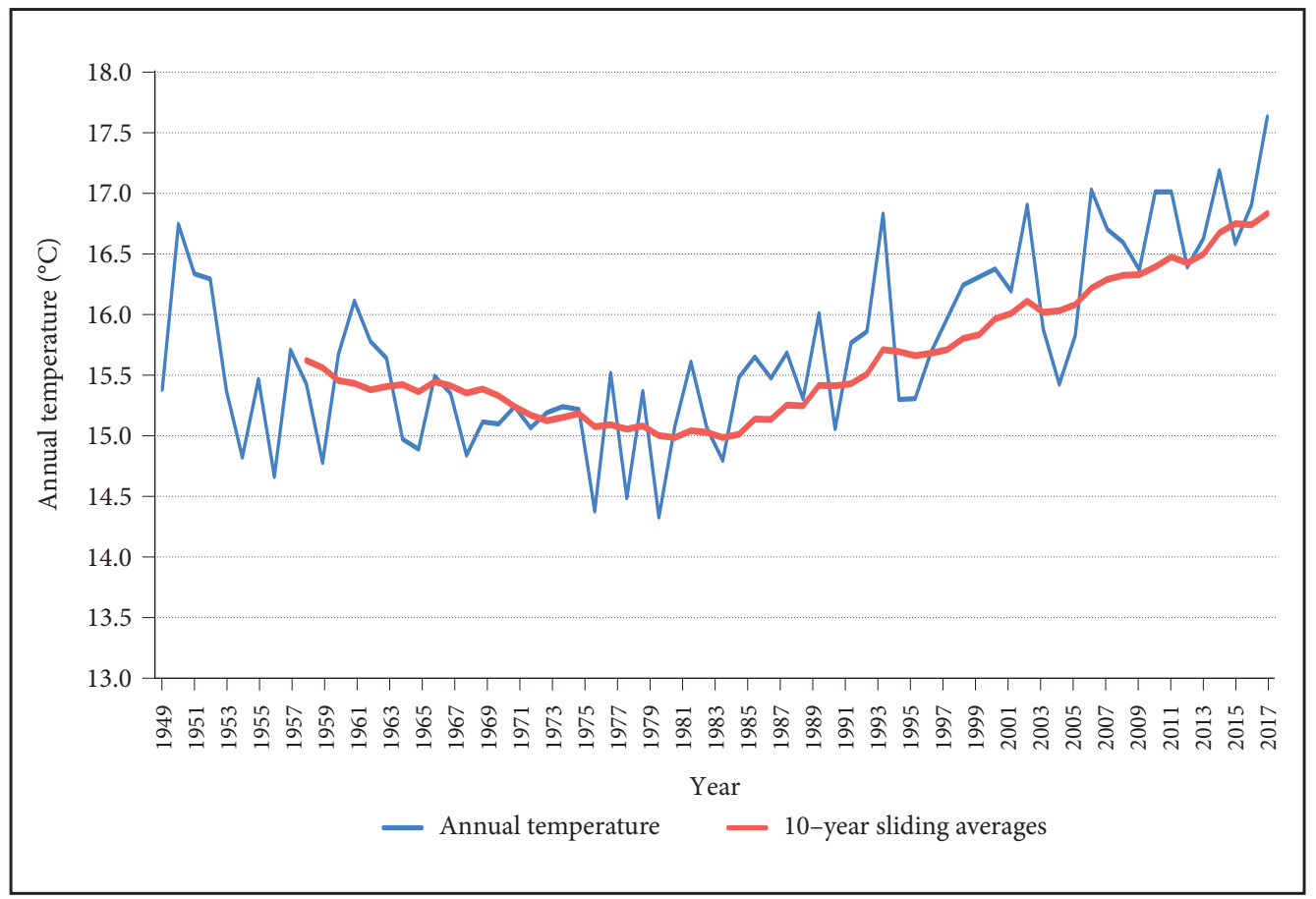

Figure 9: Annual air temperature at Podgorica, 1949-2018 (Internet 1). 

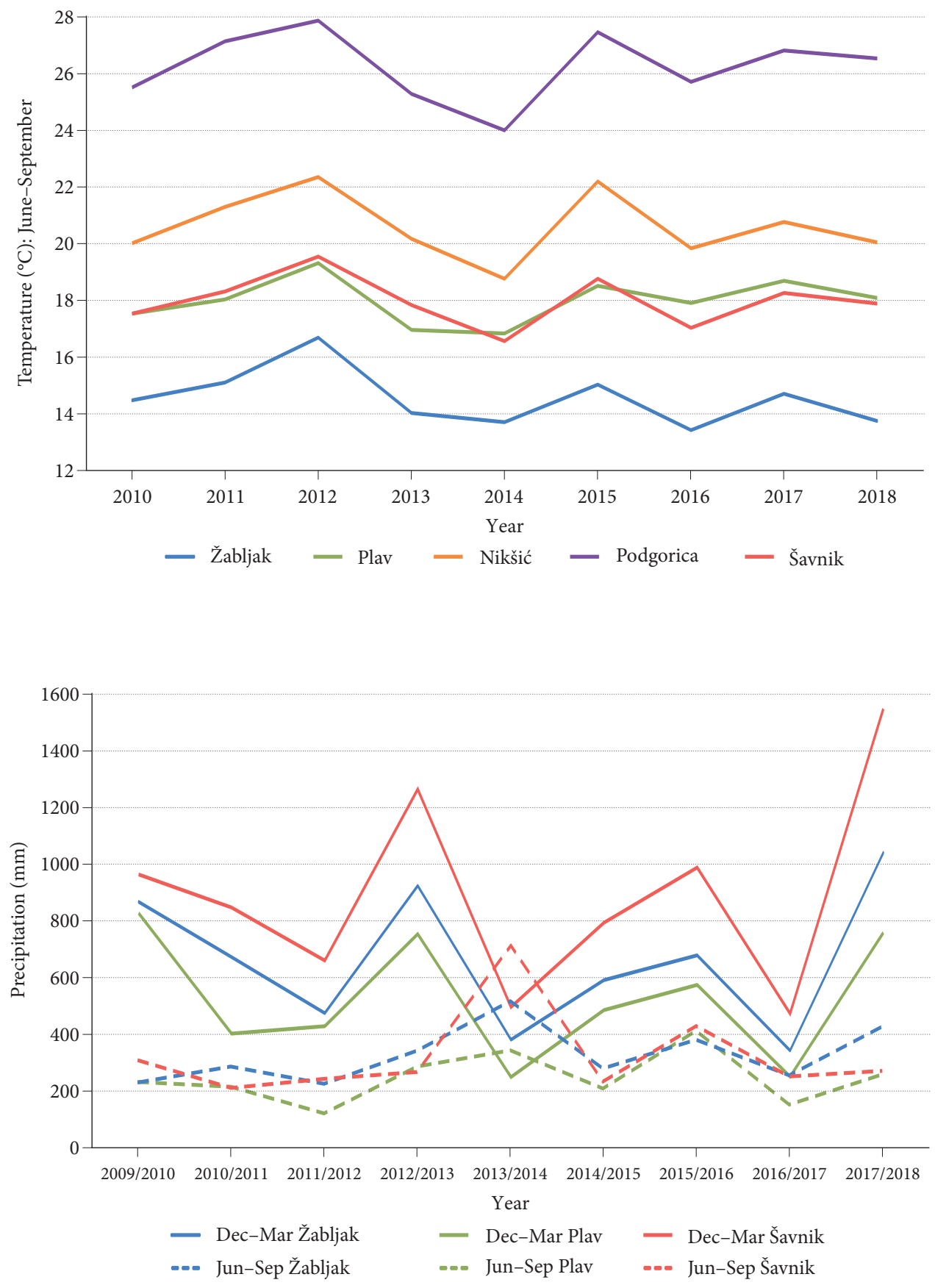

Figure 10: Summarized temperature and precipitation data for the 2010/2011 to 2017/2018 glacier mass balance years (Internet 1). 


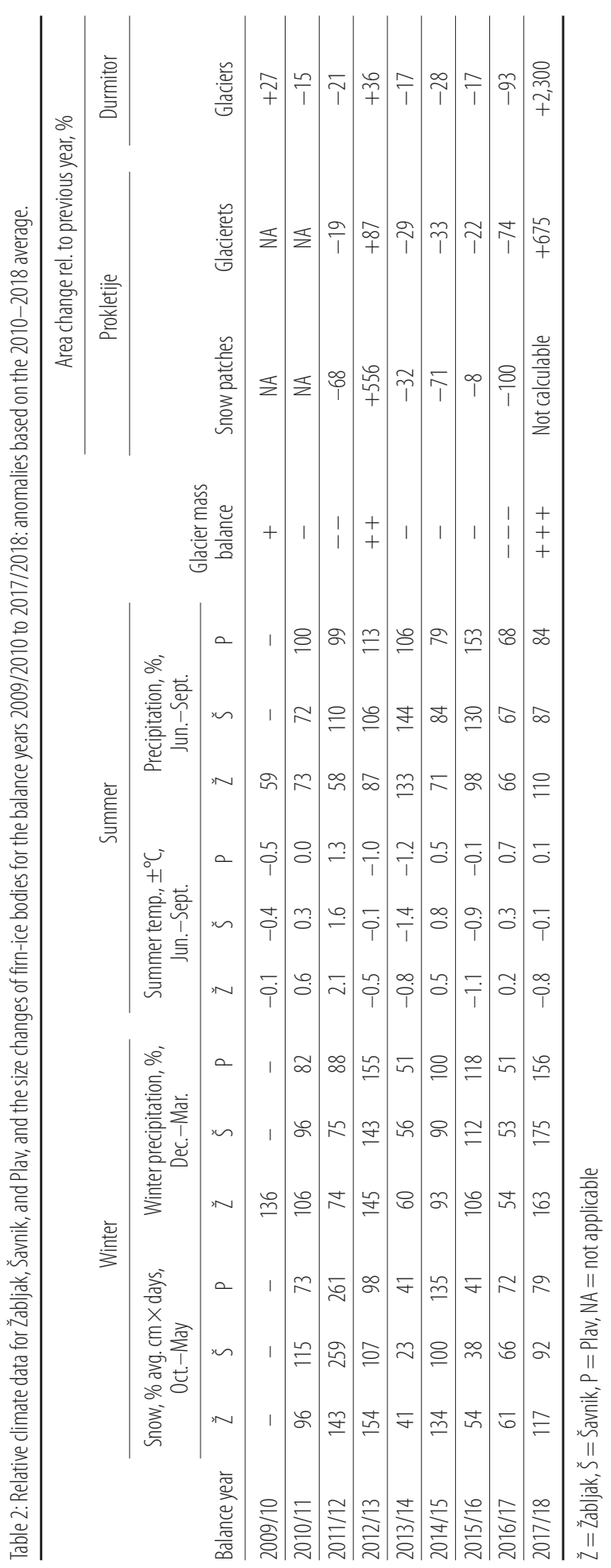


2009/2010: a 27\% increase in the size of the Debeli Namet Glacier was caused by a snowy winter, a cool summer, and rare summer rains.

2010/2011: At Žabljak, winter precipitation was $22 \%$ lower than during the previous winter but still moderate, and the summer temperature was $0.7^{\circ} \mathrm{C}$ higher than in 2010 . The Debeli Namet Glacier shrank by $15 \%$, despite the deficit of summer rains. On the Prokletije Massif, the winter was a little drier, and summer precipitation was higher, which was compensated by lower summer temperatures. However, the size of glacierets remained considerable.

2011/2012: December and March were dry, but in February a record heavy snow fell across Montenegro. The snow cover remained deep for a long time because of very low temperatures, weak snow compaction, and low melt rates. Nonetheless, the total amount of winter precipitation was low. The heavy snowfall triggered avalanches that piled deep snow on cirque floors. This lengthened the melt period in the spring and helped small glaciers survive the extremely hot and dry summer, with only around $20 \%$ area loss. However, the snow patches on the Prokletije Massif were greatly affected by the heat.

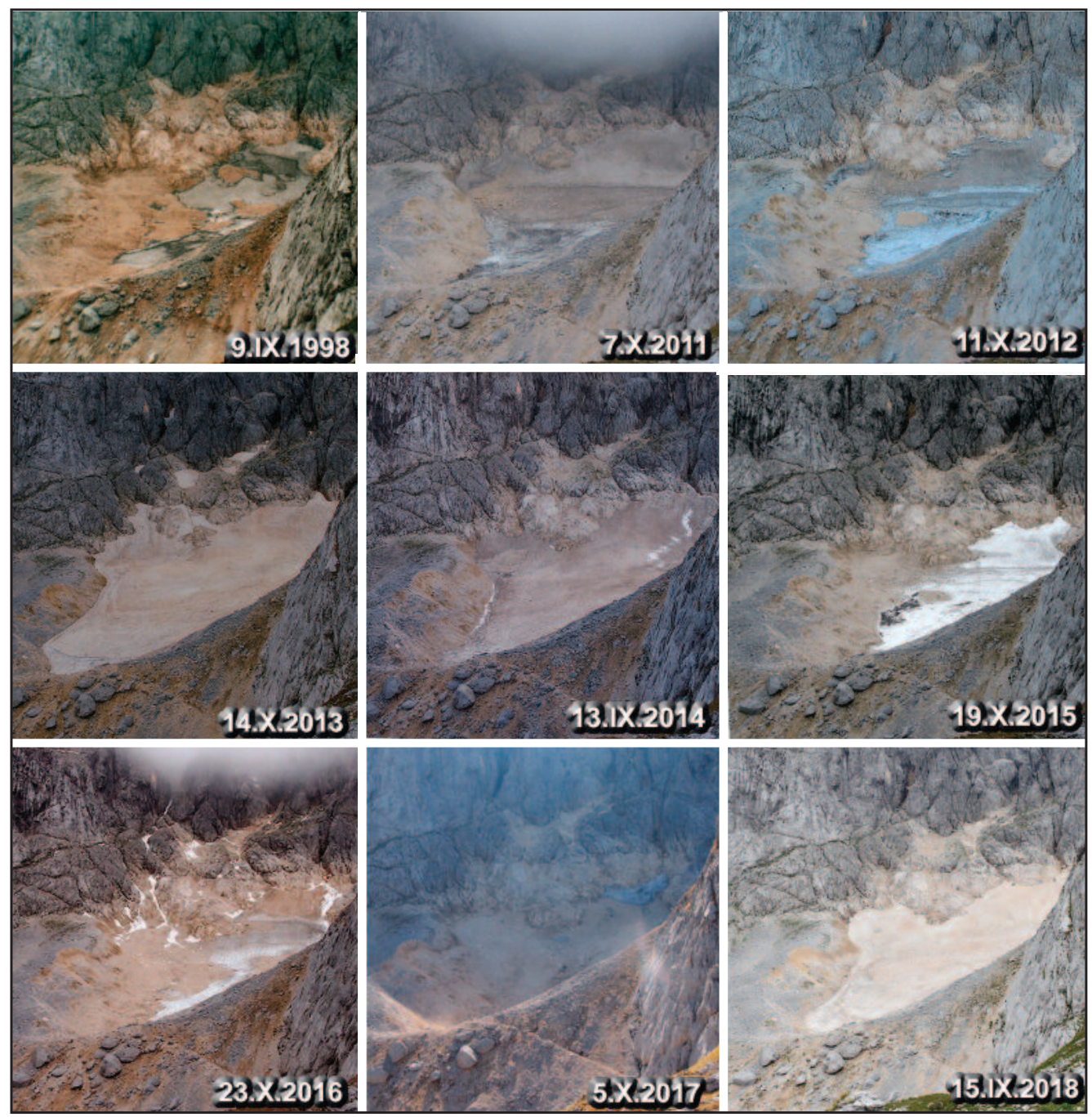

Figure 11: The Debeli Namet Glacier at the end of the balance year: 1998 and 2011-2018. 
2012/2013: The snow cover was thinner than in 2011/2012, but it lasted longer due to the much higher and evenly distributed winter precipitation. The damp and moderately cold winter was followed by a cool summer. All firn-ice bodies expanded, reaching sizes comparable to those in 2006.

2013/2014: a very warm winter $\left(+3\right.$ to $+5^{\circ} \mathrm{C}$ anomalies in February) with very low precipitation and extremely low snow cover provided modest accumulation. The summer was the coldest in the period studied, which was crucial for preserving glaciers from severe shrinkage. Abundant summer rains contributed to a glacier retreat in the range of 17 to $32 \%$. The retreat was more due to rains than temperature.

2014/2015: Moderate winter accumulation (precipitation around and below average with a short episode of heavy snow in March) combined with a warm summer resulted in another shrinkage of small glaciers by 28 to $33 \%$, and $71 \%$ of low-elevation snow patches.

2015/2016: Winter precipitation was average but the snow cover was very thin. Precipitation was evenly distributed, and avalanche activity was low. This caused earlier ablation. Summer temperatures were low, but the amounts of rain were above average. As a result, a slight decrease was recorded (from 8 to $22 \%$ ). 2016/2017: The driest winter with the least snow during the period analyzed was followed by a dry and warm summer (July and August were had even higher temperatures). This resulted in catastrophic shrinkage and the disappearance of almost all firn-ice bodies (Figure 11). This situation was supported by their very low starting size from the previous autumn.

2017/2018: a high positive mass balance of all firn-ice bodies was determined by the wet winter and a cool to moderate summer. Avalanche snow delayed the start of active ablation in cirques.

2018/2019: The winter was moderately wet (with much less snow than in 2017/2018), whereas the summer was warm, with little rain. As a result, a negative mass balance and recession was again recorded (the Debeli Namet Glacier shrank by a third).

\section{Discussion}

Firn-ice bodies in the highest parts of the Dinaric range have recently demonstrated a specific pattern of short-term variations: considerable accumulation in a particular year (»recharge «) followed by several years of gradual decrease. Such behavior is mostly determined by short-term fluctuations in winter precipitation.

Interannual changes in small firn-ice bodies across southern Europe typically have high amplitudes (Hughes 2008). In the wider region, variations are sometimes synchronous but often demonstrate a »staggered « pattern, determined by different climate factors.

Glacierets in the Pirin Mountains of Bulgaria with a more continental climate are less variable, in both the long and short terms (see Table 1). Their short-term fluctuations are mainly driven by changes in summer temperature, and winter precipitation plays a secondary role (Gachev 2016). The heatwaves in the summers of 2012, 2017, and 2019 caused record minimums of those glacierets, but in the last twentyfive years interannual changes have been more often controversial, and gradual decrease series were rarely recorded.

In contrast, the firn-ice patches in the High Tatras show contrasting patterns of short-term variation among themselves, which are not closely related to temperature, due to the strong effect of intensive summer rains, which are of an accidental character and might affect only particular sites (Gądek 2008).

In a longer-term context, the post-LIA recession of the glaciers in the Mediterranean has comprised periods of rapid retreat, separated by episodes of relative stagnation, and even minor advances. Many of the very small glaciers today on the southeast periphery of the Alps, the Apennines, and the Pyrenees had much larger extents in the past and underwent immense shrinkage between the 1970s and the 2000s, mainly as a result of temperature rise (D'Orefice et al. 2000; Gabrovec et al. 2014; Colucci et al. 2014; Pecci, D’Agata and Smiraglia 2008). In the last two decades, many of those glaciers have turned into glacierets and entered a stagnation phase: being restricted to only the most favorable locations, these tiny bodies came under increased topoclimatic control, and they »decoupled « to some extent from the global climate.

"Decoupling « depends on size. The threshold size depends on the particular topography of each site, and it is usually not larger than 1 to 5 hectares. The glaciers in the Dinaric range underwent this stage much earlier than those in the southeastern Alps and the Apennines, probably in the first decades of the twentieth century, and those in the Pirin Mountains were probably in a "decoupled « state already during the 
LIA. Since the 1950s, small glaciers in the Balkans have demonstrated relatively modest trends of shrinkage (Djurović 2012; Grunewald, Scheithauer and Gikov 2008). In contrast, some of the larger cirque glaciers in the Mediterranean, such as Mount Perdido in the Pyrenees or Mount Marmolada in the Dolomites, still have not reached the decoupling size threshold. However, they have been subject to rapid recession in recent decades (Lopez-Moreno et al. 2016; Santin et al. 2019).

Despite the fact that glacierets demonstrate enhanced resistance to climate change due to strong topoclimatic influences, they are not in a balanced state under the conditions of recent active warming. This is evidenced by the fact that in years with climate conditions close to average for the last decade, the net mass balance of firn-ice bodies at all locations was negative. As a result, long-term decline trends have been observed for very small glaciers everywhere in the mountains of Southern Europe. It is expected that the minimums in the interannual variation of glaciers' size will become increasingly expressed.

For the Debeli Namet Glacier, the size in 2017 was the smallest on record, far beyond the reduced sizes in the 1990s. The data available for firn-ice bodies on the Prokletije Massif, as well as the position of moraines, indicate that it is very likely that in 2017 they also reached their absolute minimum, at least since the beginning of the LIA, or perhaps even since earlier stages of the Holocene, as suggested for the Triglav Glacier by Lipar et al. (2020).

\section{Conclusion}

In the highest mountain massifs of the Dinaric range, there are still many permanent firn-ice bodies. Their recent interannual behavior reflects the effects of regional climate change. Recently, six small glaciers and two sustainable snow patches have demonstrated great short-term variations of size and a downward longterm trend.

Winter precipitation is of major importance for short-term glacier variations. In recent years, the variation pattern of winter precipitation consisted of separate winters with a high volume of snow, when small glaciers and snow patches increased, followed by two to four drier winters. The rising temperatures increase ablation and make the minimums in the size of snow patches and glaciers increasingly severe.

In years when climate conditions were around the averages for the latest period (2010-2018), small to moderate glacier shrinkage was observed. Therefore, current average conditions do not support the longterm existence of small glaciers in the highest mountain regions of the Dinaric range.

From 2013 to 2017, the eight monitored firn-ice bodies underwent gradual recession, effectively turning into ice patches. After the summer of 2017, six of them had completely melted, leaving only fields of debris mixed with ice at some locations. Considering the temperature changes, this has probably been the smallest ice extent since the beginning of the LIA. The reason was the observed sequence of four years with scant winter precipitation, thin snow cover, and relatively small avalanche activity, when the earlier disappearance of the snow cover caused longer ablation times across glacier surfaces. During the summers of 2014 to 2017, small glaciers and snow patches were subjected to enhanced ablation either by heat waves (in 2015 and 2017) or by abundant rains (in 2014 and 2016).

Summer temperature is a leading factor in the long-term evolution of firn-ice bodies. This is why, despite the recent increase in average winter precipitation, the continuing rise of temperatures will likely lead to the disappearance of small glaciers in the Dinaric Mountains in the foreseeable future if present trends persist. Glacierets will be downgraded to ice patches and snow patches sooner than the glacierets in the Pirin Mountains due to the higher amplitude of their size variation. This might become a fact in the next decade.

ACKNOWLEDGEMENTS: I am very grateful to the Southwest University of Blagoevgrad for providing funding for this research through the following grants: SRP-B3/2012, SRP-B4/2013, SRP-B3/2014, SRPA10/2015, RP-B4/2016, RP-A13/2017, and RP-A4/2018. The research results are also connected with the project FNI 02/70 (BMES, 2014-2016). I would also especially like to thank Matija Zorn from the ZRC SAZU Anton Melik Geographical Institute in Slovenia and Predrag Djurović from the University of Belgrade in Serbia for their support and encouragement, and also the journal reviewers and editors for their constructive remarks. 


\section{References}

Burić, M., Micev, B., Mitrović, L. 2012: Atlas klime Crne gore. Podgorica.

Cerović, B. 1991: Durmitor i kanjon Tare. Beograd.

Colucci, R. R. 2016: Geomorphic influence on small glacier response to post Little Ice Age climate warming: Julian Alps, Europe. Earth Surface Processes and Landforms 41-9. DOI: https:/doi.org/10.1002/esp.3908

Colucci, R. R., Forte, E., Boccali, Ch., Dossi, M., Lanza, L., Pipan, M., Guglielmin, M. 2014: Evaluation of Internal Structure, Volume and Mass of Glacial Bodies by Integrated LiDAR and Ground Penetrating Radar Surveys: The Case Study of Canin Eastern Glacieret (Julian Alps, Italy). Surveys in Geophysics 36(2). DOI: 10.1007/s10712-014-9311-1

Colucci, R. R., Žebre, M. 2016: Late Holocene evolution of glaciers in the southeastern Alps Journal of Maps, 12-1. DOI: https://doi.org/10.1080/17445647.2016.1203216

Del Gobbo, C., Colucci, R. R., Forte, E., Triglav Čekada, M., Zorn, M. 2016: The Triglav Glacier (SouthEastern Alps, Slovenia): Volume Estimation, Internal Characterization and 2000-2013 Temporal Evolution by Means of Ground Penetrating Radar Measurements. Pure Applied Geophysics 173. DOI: https://doi.org/10.1007/s00024-016-1348-2

Dimitrijević, M. 1983: Osnovna geološka karta SFRJ , 1:100 000, List Gusinje. Savezni geološki zavod. Belgrade.

Djurović, P. 1999: Natural and anthropogenic influences as threats to pits in the Debeli namet glacier, Durmitor National park, Montenegro. Contribucion del estudio cientifico de las cavidades karsticas al conocimiento geologico. Malaga.

Djurović, P. 2009: Reconstruction of the Pleistocene glaciers on Mount Durmitor in Montenegro. Acta geographica Slovenica 49-2. DOI: https://doi.org/10.3986/AGS49202

Djurović, P. 2011: Visokoplaninski kras Durmitora. Beograd.

Djurović, P. 2012: The Debeli Namet glacier from the second half of the 20th century to the present. Acta geographica Slovenica 52-2. DOI: https://doi.org/10.3986/AGS52201

D’Orefice, M., Pecci, M., Smiraglia, C., Ventura, R. 2000: Retreat of Mediterranean glaciers since the Little Ice Age: Case study of Ghiacciaio del Calderone, Italy. Arctic, Antarctic and Alpine Research 32-2. DOI: https://doi.org/10.2307/1552451

Ducić, V., Burić, D., Luković, J., Stanojević, G. 2011: Promjene količine padavine u Podgorici u periodu 1951-2010. Glasnik Srpskog geografskog društva 91-2.

Gabrovec, M., Hrvatin, M., Komac, B., Ortar, J., Pavšek, M., Topole, M., Triglav Čekada, M., Zorn, M. 2014: Triglavski ledenik. Ljubljana.

Gachev, E. 2016: Klimatichni faktori za mezhdugodishnata dinamika na mikrolednik Snezhnika v Pirin. Proceedings of the Scientific conference „Geographical aspects of spatial planning and utilization in global change conditions «. Varshets.

Gachev, E. 2017: The Unknown Southernmost Glaciers of Europe. Glaciers evolution in a changing world. Zagreb. DOI: htttps://doi.org/10.5772/intechopen.68899

Gachev, E., Mitkov, I. 2019: Small glaciers in Pirin (Bulgaria) and Durmitor (Montenegro) as glacio-karstic features. Similarities and differences in their behaviour. Quaternary International 504. DOI: https://doi.org/ 10.1016/j.quaint.2018.03.032

Gachev, E., Stoyanov, K. 2012: Present-day perennial firn/ice patches in the mountains of the Western Balkan peninsula. Studia geomorphologica carpatho-balcanica 46.

Gachev, E., Stoyanov, K., Gikov, A. 2016: Small glaciers on the Balkan Peninsula: state and changes in the last several years. Quaternary International 415. DOI: https://doi.org/10.1016/j.quaint.2015.10.042

Gądek, B. 2008: The problem of firn-ice patches in the polish tatras as an indicator of climatic fluctuations. Geographia Polonica 81-1.

Godišnjak meteoroloških i hidroloških podataka, 2010. Zavod za hidrometeorologiju i seizmologiju Crne Gore. Podgorica, 2019.

Godišnjak meteoroloških i hidroloških podataka, 2011. Zavod za hidrometeorologiju i seizmologiju Crne Gore, Podgorica, 2018.

Godišnjak meteoroloških i hidroloških podataka, 2012. Zavod za hidrometeorologiju i seizmologiju Crne Gore, Podgorica, 2014.

Godišnjak meteoroloških i hidroloških podataka, 2013. Zavod za hidrometeorologiju i seizmologiju Crne Gore, Podgorica, 2016. 
Godišnjak meteoroloških i hidroloških podataka, 2014. Zavod za hidrometeorologiju i seizmologiju Crne Gore, Podgorica, 2016.

Godišnjak meteoroloških i hidroloških podataka, 2015. Zavod za hidrometeorologiju i seizmologiju Crne Gore, Podgorica, 2018.

Godišnjak meteoroloških i hidroloških podataka, 2016. Zavod za hidrometeorologiju i seizmologiju Crne Gore, Podgorica, 2019.

Godišnjak meteoroloških i hidroloških podataka, 2017. Zavod za hidrometeorologiju i seizmologiju Crne Gore, Podgorica, 2019.

Godišnjak meteoroloških i hidroloških podataka, 2018. Zavod za hidrometeorologiju i seizmologiju Crne Gore, Podgorica, 2019.

Grunewald, K., Scheithauer, J. 2008: Klima- und Landschaftgeschichte Sudosteuropas. Rekonstruktion anhand von Geoarchiven im Piringebirge (Bulgarien). Berlin.

Grunewald, K., Scheithauer, J. 2010: Europe's southernmost glaciers: response and adaptation to climate change. Glaciology 56-195. DOI: https://doi.org/10.3189/002214310791190947

Grunewald, K., Scheithauer, J. 2011: Landscape development and climate change in Southwest Bulgaria (Pirin Mountains). Dordrecht. DOI: https://doi.org/10.1007/978-90-481-9959-4

Grunewald, K., Scheithauer, J., Gikov, A. 2008: Mikrolednitsi v Pirin planina. Problems of Geography 1-2.

Hohenwarter, G. 2013: The Eiskar - 115 years of measurements at the southernmost glacier in Austria. Meteorologica 12-2.

Hughes, P. D. 2007: Recent behaviour of the Debeli Namet glacier, Durmitor, Montenegro. Earth Surface Processes and Landforms 32. DOI: https://doi.org/10.1002/esp.1537

Hughes, P. D. 2008: Response of a Montenegro glacier to extreme summer heatwaves in 2003 and 2007. Geografiska Annaler: Series A, Physical Geography 90-4. DOI: https://doi.org/10.1111/j.1468-0459. 2008.00344.x

Hughes, P. D. 2009: Twenty-first century glaciers in the Prokletije mountains, Albania. Arctic, Antarctic and Alpine Research 41-4. DOI: https://doi.org/10.1657/1938-4246-41.4.455

Hughes, P. D. 2010: Little Ice Age glaciers in the Balkans: low altitude glaciation enabled by cooler temperatures and local topoclimatic controls. Earth Surface Processes and Landforms 35-2. DOI: https://doi.org/ 10.1002/esp.1916

Hughes, P. D., Woodward, J. C. 2008: Timing of glaciation in the Mediterranean mountains during the last cold stage. Journal of Quaternary Science 23. DOI: https://doi.org/10.1002/jqs.1212

Hughes, P. D., Woodward, J. C., van Calsteren, P. C., Thomas, L. E. 2011: The glacial history of the Dinaric Alps, Montenegro. Quaternary Science Reviews 30, 23-24. DOI: https://doi.org/10.1016/j.quascirev. 2011.08.016

Internet 1: www.meteo.co.me (15. 1.2020).

Internet 2: www.monstat.org (15. 1. 2020).

Kern, Z., Surányi, G., Molnár, M., Nagy, B., Balogh, D. 2007: Investigation of natural perennial ice deposits of Durnitor Mts., Montenegro. Proceedings of the 2nd workshop in ice caves. Demanovská dolina.

Lipar, M., Pérez, A. M., Tičar, J., Pavšek, M., Gabrovec, M., Hrvatin, M., Komac, B., Zorn, M., Zupan Hajna, N., Zhao, J.-X., Ferk, M. 2020: Subglacial carbonate deposits as a potential proxy for glacier's existence. The Cryosphere. https://doi.org/10.5194/tc-2020-82

Lopez-Moreno, J., Revuelto, J., Rico, I., Chueca-Cía, J., Julián, A., Serreta, A., Serrano, E., Vicente-Serrano, S., Azorin-Molina, C., Alonso-González, E., García-Ruiz, J. 2016: Thinning of the Monte Perdido Glacier in the Spanish Pyrenees since 1981. The Cryosphere 10. DOI: https://doi.org/10.5194/tc-10-681-2016

Milivojević, M., Menković, L., Ćalić, J. 2008: Pleistocene glacial relief of the central part of Mt. Prokletije (Albanian Alps). Quaternary International 190-1. DOI: https://doi.org/10.1016/j.quaint.2008.04.006

Mirković, M. 1983: Geološki sastav i tektonski sklop Durmitora, Pivske planine i Volujka. Geološki glasnik 5.

Nicod, J. 1968: Premières recherches de morphologie karstique dans le massif du Durmitor. First studies of karst morphology in the massif of Durmitor. Meditérrannée 9-3.

Pavšek, M. 2007: Ledenik pod Skuto kod pokazatelj podnebnih sprememb v slovenskem delu Alp. Dela 28.

Pecci, M., D'Agata, C., Smiraglia, C. 2008: Ghiacciaio del Calderone (Apennines, Italy): the mass balance of a shrinking glacier. Geografia Fisica e Dinamica Quaternaria 31.

Popov, V. 1964: Nabljudenia varhu snezhnika v tsirkisa Golemia Kazan - Pirin planina. Izvestia na Geografskia institut 8 . 
Roth von Telegd L. 1923: Das albanisch-montenegrinische Grenzgebiet bei Plav (Mit besonderer Berücksichtigung der Glazialspuren). Beiträge zur Geologie von Albanien, Neues Jahrbuch für Mineralogie 1. Stuttgart.

Santin, I., Colucci, R. R., Žebre, M., Pavan, M., Cagnati, A., Forte, E. 2019: Recent evolution of Marmolada glacier (Dolomites, Italy) by means of ground and airborne GPR surveys. Remote Sensing of Environment 235. DOI: https://doi.org/10.1016/j.rse.2019.111442

Serrano, E., González Trueba, J., Sanjosé, J., Del Río, L. 2011: Ice patch origin, evolution and dynamics in a temperate high mountain environment: The Jou Negro, Picos de Europa (NW Spain). Geografiska Annaler Series a Physical Geography 93-2. DOI: 10.1111/j.1468-0459.2011.00006.x.

Wilkinson, R. 2011: a multi-proxy study of late holocene environmental change in the Prokletije Mountains, Montenegro and Albania. Ph.D thesis, University of Manchester. Manchester.

Zemp, M., Paul, F., Hoelzle, M., Haeberli, W. 2008: Glacier fluctuation in the European Alps, 1850-2000: an overview and a spatio-temporal analysis of available data. Darkening Peaks: Glacier Retreat, Science, and Society. DOI: https://doi.org/10.5167/uzh-9024 